\title{
The Anti-inflammatory Effect of Ethanol Extract Gel of Fig Leaves (Ficus carica Linn.) and Sidr Leaves (Ziziphus mauritiana Linn.)
}

\author{
Muhammad Fariez Kurniawan*, Ariffadli Prakoso, Muhammad Indra Irawan \\ Department of Pharmacy Technology, School of Pharmacy, Faculty of Medicine and Health Sciences, Universitas Muhammadiyah \\ Yogyakarta, Yogyakarta, INDONESIA.
}

\begin{abstract}
Inflammation is a form of the body's response to tissue damage with a sign of epidermal thickness, an increase in the number of inflammatory cells and the expression of the COX-2 enzyme. The fig leaves and sidr dry leaves are among the natural ingredients that are used to intervene in inflammation. This study aims to identify the anti-inflammatory effects of ethanol extract of the two natural ingredients formulated in the form of a gel. This study probed 15 groups of research subjects of BALB/c rats (Mus musculus), which were given several treatments. The test parameters were administered on the physical characteristics of gel preparations in the form of organoleptic, $\mathrm{pH}$, spread ability, adhesion and viscosity of the gel as well as anti-inflammatory activity test based on epidermal thickness, a number of inflammatory cells and COX-2 expression. The rats were treated for 3 days before the process of histopathological preparation, Hematoxylin Eosin and COX-2 immunohistochemistry. The results implied that the extracted gel of fig and sidr leaves showed good physical characteristics in the organoleptic, $\mathrm{pH}$ 5.73$6.12,3.29 \mathrm{~cm}$ spread ability, 2.98 seconds adhesion and pseudoplastic fluid. The antiinflammatory activity displayed significant differences in the treatment group, which were $2.5 \%$ of sidr leaves extract, $5 \%$ of sidr leaves extract, $2.5 \%$ of fig leaves extract, $5 \%$ of fig leaves extract, $2.5 \%$ of fig and sidr leaves extract combination, $5 \%$ of fig and sidr leaves extract combination, $2.5 \%$ of sidr leaves gel, $5 \%$ of sidr leaves gel, $2.5 \%$ of fig leaves gel, $5 \%$ of fig leaves gel, $2.5 \%$ of fig and sidr leaves gel combination and $5 \%$ of fig and sidr leaves gel combination compared to negative control. However, when it was juxtaposed with normal and positive control, a conclusion of the treatment group had better activity in reducing the thickness of the epidermis could not be drawn.
\end{abstract}

Key words: Anti-inflammatory activity, COX-2 enzyme, Inflammatory cells, Fig leaves, Sidr leaves, Gel.

\section{INTRODUCTION}

Inflammation is one of the pathological processes that underlie various diseases and cause clinical symptoms. The inflammatory response is characterized by circumstances, such as swelling (tumor), fever (heat), redness in the inflammatory area (rubor), pain (dolor), and functional tissue disruption (functio lasa). ${ }^{1}$ Inflammation activates cells in the tissue, thereby it can increase the release of pro-inflammatory mediators and leukocytes. ${ }^{2}$ The pro-inflammatory mediator produced is prostaglandin due to an increase in expression and activity of the cyclooxygenase- 1 and 2 enzymes (COX-1 and COX-2). According to Kamatou, et al. ${ }^{3}$ this enzyme increases during inflammation and carcinogenesis process and it is found that inhibition of the COX-2 enzyme has the potential to be considered as an antiinflammatory or chemopreventive agent.

The fig leaves (Ficus carica Linn.) and Sidr leaves (Zizhipus mauritiana Linn.) are the
Submission Date: 22-07-2020; Revision Date: 25-12-2020; Accepted Date: 19-05-2021

DOI: 10.5530/ijper.55.2s.123 Correspondence: Mr. Muhammad Fariez Kurniawan

Department of Pharmacy Technology, School of Pharmacy, Faculty of Medicine and Health Sciences, Universitas Muhammadiyah Yogyakarta, Yogyakarta, INDONESIA.

Phone: +62-878-3993 3038 Email id: fariez@umy.ac.id

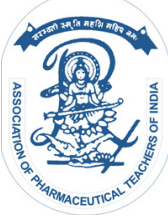

www.ijper.org 
plants' parts used in Traditional Arab Medicine. The fig leaves contain polyphenols, especially flavonoid compounds which are used as antibacterial, antioxidant, antitumoral, and also for the treatment of inflammation. ${ }^{4}$ Meanwhile, the sidr leaves contain polyphenols especially flavonoids, alkaloids, terpenoids, and saponin compounds ${ }^{5}$ which have potentials as antioxidants ${ }^{6}$ antitumoral, and anticancer, ${ }^{7}$ antibacterial, ${ }^{5}$ thrombolytic, ${ }^{8}$ and anti-inflammatory agents. ${ }^{9}$ The studies on the effectiveness of fig and sidr leaves as an anti-inflammation have been reported. The research conducted by Patil et al. ${ }^{10}$ showed that ethanol extracts of fig leaves contain flavonoids that have the effect of being anti-inflammation whose strength is almost similar to the Non-Steroidal Anti-Inflammatory Drug (NSAID)-Indometasin group. The flavonoid content of fig leaves inhibits the formation of pro-inflammatory components which its role is as an anti-inflammatory effect. ${ }^{11}$ The anti-inflammatory activity of sidr leaves also shows the results similar to the anti-inflammatory effects of the Indometasin drug. ${ }^{12}$

In the previous study, the administration of figs leaves and sidr leaves extract in cream dosage form proven to have efficacy in reducing epidermal thickness, a number of inflammatory cells and expression of COX-2 enzymes. But the resulting cream dosage form is less comfortable to use. ${ }^{13}$ A gel is a topical dosage form widely opted by the public, both for medicine and cosmetics. It is a semi-solid preparation, which consists mainly of water without a fluid activity. It is elastic but retains its water properties ${ }^{14}$ containing the cold sensation on the skin, being easy to dry and wash are the advantages of the gel that people are commonly fond of. Another advantage possessed by the gel is the good ability to release drugs. It can spread appropriately into the skin and does not inhibit the physiological function of the hair. ${ }^{15}$ Based on the explanation above, the researchers' are interested in producing anti-inflammatory gel preparations containing ethanolic extracts of fig leaves and sidr leaves.

\section{MATERIALS AND METHODS}

This study utilized animals, namely BALB/c rats obtained from Laboratory of Integrated Research and Testing Gadjah Mada University, Yogyakarta, as the research subject. A total of 90 rats was divided into 15 groups to be conducted an anti-inflammatory observation. This study was approved by the UMY Ethics Committee Number 427/EP-FKIK-UMY//IX/2018.

\section{Materials}

The tools utilized in this study were analytical scales (Mettler Toledo ${ }^{\circledR}$ ), blenders $\left(\right.$ Airlux $\left.x^{\circledR}\right)$, glass wares
(Pyrex and Iwaki $\left.i^{\circledR}\right)$, Buchner funnels, funnels $\left(\right.$ Herma $\left.^{\circledR}\right)$, volumetric pipettes $\left(\right.$ Pyrex $\left.{ }^{\mathbb{R}}\right)$, porcelain plates $\left(\right.$ Pyrex $\left.^{\mathbb{R}}\right)$, filter papers $\left(\right.$ Whatman $\left.^{\mathbb{B}}\right)$, aluminium foils $\left(\right.$ Diamond $\left.^{\mathbb{B}}\right)$, rotary evaporator $\left(I K A^{\circledR}\right)$, water bath $\left(\right.$ Memmert $\left.^{\circledR}\right)$, $\mathrm{pH}$ meter ( Seven Easy Mettler Tholedo ${ }^{\circledR}$ ), Microscope ( Olympus ${ }^{\circledR}$ ), Digital Stirring Hotplates ( Thermo Fisher Scientific Cimarec $\left.{ }^{\circledR}\right)$, Merlin VR 2 Reeosis viscometer, ultraturrax (IKA ${ }^{\circledR}$ T25 Digital), jars, pro pipettes, stirring rods, gel stickiness test kits, gel dispersion test kits and veterinary surgical instruments. The materials used in this study were dry simplifies of fig leaves (Ficus carica Linn. ) and sidr leaves (Zižhipus mauritiana Linn.) procured from Zam Zam Home Therapy distributor, croton oil to induce inflammation in rats obtained from sigma distributor, $70 \%$ of ethanol (Brataco ${ }^{\circledR}$ ) for maceration, phytochemical screening reagents and extract standardization, ingredients for formulating anti-inflammatory gel preparations such as ethanolic extracts of fig and sidr leaves, carbopol $940\left(\right.$ Brataco $\left.^{\circledR}\right)$, TEA $\left(\right.$ Brataco $\left.^{\circledR}\right)$, sorbitol $\left(\right.$ Brataco $\left.^{\circledR}\right)$, liquid paraffin $\left(\right.$ Brataco $\left.^{\circledR}\right)$, methylparaben $\left(\right.$ Brataco $\left.^{\circledR}\right)$, propylparaben $\left(\right.$ Brataco $\left.^{\circledR}\right)$, Voltaren ${ }^{\circledR}$ emulgel containing diclofenac sodium (Formulation A) were produced by Novartis Pharmaceuticals. The tested animals used were 2 to 3-month $\mathrm{BALB} / \mathrm{c}$ rats.

\section{Gel Formulation}

The anti-inflammatory gel formulation of fig leaves and sidr leaves is presented in Table 1. The gel production was carried out by using carbopol 940 base swelling

\begin{tabular}{|c|c|c|c|c|c|c|}
\hline \multirow{2}{*}{\multicolumn{2}{|c|}{$\begin{array}{l}\text { Material } \\
\text { GB } 2.5 \%\end{array}$}} & \multicolumn{5}{|c|}{ Formula } \\
\hline & & GB & $\begin{array}{c}\text { GF } \\
\end{array}$ & GF & GC & GC \\
\hline Extract & 2.5 & 5 & 2.5 & 5 & 2.5 & 5 \\
\hline Carbopol 940 & 2 & 2 & 2 & 2 & 2 & 2 \\
\hline $\begin{array}{l}\text { Triethanolamine } \\
\text { (TEA) }\end{array}$ & 2.6 & 2.6 & 2.6 & 2.6 & 2.6 & 2.6 \\
\hline Sorbitol & 2 & 2 & 2 & 2 & 2 & 2 \\
\hline Liquid Paraffin & 1.25 & 1.25 & 1.25 & 1.25 & 1.25 & 1.25 \\
\hline Methylparaben & .18 & 18 & .18 & .18 & 18 & .18 \\
\hline Propylparaben & 0.02 & 0.02 & 0.02 & 0.02 & 0.02 & 0.02 \\
\hline Aquadest ad & 100 & 100 & 100 & 100 & 100 & 100 \\
\hline $\begin{array}{l}\text { Note : } \\
\text { GB 2.5\%: Gel with 2. } \\
\text { GB 5\%: Gel with } 5 \% \\
\text { GF 2.5\%: Gel with 2. } \\
\text { GF 5\%: Gel with } 5 \% \\
\text { GC 2.5\%: Gel with 2. } \\
\text { GC 5\%: Gel with 5\% }\end{array}$ & $\begin{array}{l}6 \text { of sidr } \\
\text { sidr lea } \\
6 \text { of fig l } \\
\text { fig leav } \\
\text { of fig a } \\
\text { fig and }\end{array}$ & $\begin{array}{l}\text { aves ex } \\
\text { s extra } \\
\text { ves extı } \\
\text { extract } \\
\text { sidr le }\end{array}$ & & $\begin{array}{l}o m b \\
\text { binat }\end{array}$ & & \\
\hline
\end{tabular}


up with normal temperature and heat aquadest which was slowly stirred and cooled for 24 hrs until the base was swelled. Triethanolamine (TEA), fig leaves and sidr leaves extract, sorbitol, methylparaben, propylparaben, liquid paraffin, and aquadest were added into the formulation until the volume reached $100 \mathrm{ml}$. The addition of materials started from the ones with the same compounds as the basis of carbopol 940, while the materials different from the base were added in heat temperature and cooled. Furthermore, the gel was put into a proper container and tightly closed. The gel formulations are shown in Table 1.

\section{The Evaluation of Gel Physical Properties}

\section{Determination of $\mathrm{pH}$}

Gel of $0.5 \mathrm{~g}$ was diluted in $5 \mathrm{ml}$ aquadest and measured using a $\mathrm{pH}$ meter.

\section{Spread ability Test}

Gel of $0.5 \mathrm{~g}$ was put on a round tray. The other tray was placed on top of it for $1 \mathrm{~min}$. The diameter of the gel spreadability was measured and it was added $50 \mathrm{~g}, 100 \mathrm{~g}$, $250 \mathrm{~g}$, and $500 \mathrm{~g}$ for one minute, and the diameter was then measured. This test was repeated 3 times.

\section{Adhesion Test}

Gel of $0.25 \mathrm{~g}$ was placed on a glass object which width had been determined and stacked up along with other glass objects mounted on the test tool. Load of $1 \mathrm{~kg}$ was added for $5 \mathrm{~min}$ and was taken off along with $80 \mathrm{~g}$ of buffer load and the time was recorded until the two glass objects were released.

\section{Viscosity Test}

The test utilized instruments with viscosity measurement speeds of $0.1-60 \mathrm{rpm}$. The instrument used was the Rheosys Merlin VR II viscometer equipped with Rheosys Micra software. The viscosity scale of the tested preparation appeared on the software used in both tabular and graphical forms.

\section{The Evaluation of Anti-Inflammatory Activity}

The inflammatory induction procedure was conducted by shaving the back hair of rats with an area of $2 \times 2$ $\mathrm{cm}$. Following $24 \mathrm{hr}$, the back of the rats was dropped with $0.1 \mathrm{ml}$ of crotton oil with a $4 \%$ concentration. The application of fig leaves extract gel, sidr leaves extract gel, the combination of fig and sidr leaves extract, and voltaren ${ }^{\circledR}$ emulgel application of $200 \mathrm{mg}$ was administered $30 \mathrm{~min}$ after croton oil dripping. This treatment was conducted for three days with the same treatment procedure. The $1 \mathrm{x} 1 \mathrm{~cm}$ of dorsal skin of the rats was then taken off around the treatment area and immersed in 10\% formalin for histopathological preparat by hematoxylin eosin (HE) and immunohistochemistry COX-2 staining. These procedures were performed in the Anatomy Pathology Laboratory of the Faculty of Medicine, Universitas Gadjah Mada, and the Anatomy Pathology Laboratory of Dr. Sardjito Hospital Yogyakarta. Based on the staining results, the epidermal thickness and the COX-2 expression were measured. ${ }^{20}$ The results of the staining process could be identified upon the sample analysis process under a light microscope ( Olympus) with an enlargement of 4 to 40 times conducted at the Histological Laboratory of Faculty of Medicine and Health Sciences Universities Muhammdiyah Yogyakarta. The analysis of the number of inflammatory cells, COX-2 expression, and epidermal thickness was done using Toupview ${ }^{\circledR}$ software.

\section{RESULTS}

The fig leaves and sidr leaves were procured from Zam Zam Home Therapy. The determination of figs leaves (Ficus carica Linn.) and sidr leaves (Ziz̧hipus mauritiana Linn.) was carried out at the Biology Laboratory of Ahmad Dahlan University Yogyakarta. The results of the determination show that the plants obtained following the main ingredients used in this study are fig plants with species (Ficus carica Linn.) and sidr plants with species (Zizhipus mauritiana Linn.). The extraction method that researchers use is the maceration method. The powder of each fig leaves (Ficus carica Linn.) and sidr leaves (Zizhipus mauritiana Linn.) as much as one kilogram was included in $70 \%$ ethanol solvent in the ratio of 1 part powder dissolved with 10 parts solvent. Macerat was attained from the filtering results and then evaporated the solvent using rotary evaporator with a speed of $90 \mathrm{rpm}$ at $70^{\circ} \mathrm{C}$. The final stage of making thick extract was by heating the liquid extract from a rotary process in a $70^{\circ} \mathrm{C}$ water bath, thus, a thick extract was obtained.

The ethanol extract gel formulation of fig and sidr leaves was adopted from a previous study. An emulgel formulation examined by previous researchers used various enhancer concentrations, a combination between propylene glycol and oleic acid which can deliver the active substance of eugenol optimally. The study shows that $100 \%$ of the enhancer concentration of propylene glycol is the optimum enhancer composition that delivers the active substance of eugenol. ${ }^{16}$ However, researchers currently varied the active substances and additives by using the active ethanol extracts of fig leaves and sidr leaves, and differed the additives by 
removing enhancers and emulsifiers due to the process of hydrogel preparation formulated. The gel preparation of fig and sidr leaves extract gel was formulated in 6 formulas with different types of active substances and concentrations, namely $2.5 \%$ of sidr leaves gel, $5 \%$ of sidr leaves gel, $2.5 \%$ of fig leaves gel, $5 \%$ of fig leaves gel, $2.5 \%$ of gel combination of fig and sidr leaves, and $5 \%$ of gel combination of fig and sidr leaves as displayed in Table 2.

A carbopol was used for this gel formulation as gelling agent base due to its ability to produce good physical nonirritated properties of the gel. ${ }^{17}$ The formulation began with the process of swelling carbopol using aquadest for $24 \mathrm{hr}$. The swelling process aims to break the rigid carbopol bonds and produce acidic colloidal dispersions with low viscosity. It, therefore, would likely be mixed well with active substances and other additives. In the formula, the alkaline triethanolamine (TEA) was added to increase the $\mathrm{pH}$ of the carbopol gel base since neutralizing the $\mathrm{pH}$ of the carbopol would increase the viscosity of the gel to obtain a good gel texture. ${ }^{18} \mathrm{In}$ the formula of ethanol extract gel of fig leaves and sidr leaves, sorbitol was added as a humectant to prevent loss of the carrier substance from the preparation to prevent the process of syneresis. To prevent the growth of microorganisms, such as bacteria and fungi, methylparaben was added to the formula in combination with a paraben profile to increase its effectiveness as an anti-bacterial and fungal agent.

\section{Evaluation of Physical Properties of Gel}

The quality gel initially needs to go through several stages of testing, such as organoleptic test, $\mathrm{pH}$ test, spreadability test, adhesion test, and viscosity test. The results of the physical properties evaluation of the ethanolic extract gel in the fig leaves and the sidr leaves are shown in Table 3.

The viscosity test aims to identify the thickness of the formulated preparations. This test used the Rheosys Merlin VR II viscometer connected to the Rheosys Micra software. In the test, replication was performed three times for each formula and the average thickness was obtained at the specified rpm. The data of the thickness of the preparation at $\mathrm{rpm} 24.1$ are presented in Table 2 as follows:

Based on the viscosity testing conducted, it can be determined that the type of fluid of the ethanolic extract gel of the fig leaves and sidr leaves is non-newtonian (pseudoplastic) which is identified by a decrease in the viscosity value accompanied with an increase in the value of the share rate. According to Rao, ${ }^{19}$ the pseudoplastic fluid can also be inducated by a disproportionate rheogram and convex form. Carbopol concentration as a gelling agent can be one of the factors that influence the preparation of the viscosity. ${ }^{18}$ The increase in the amount of carbopol is following the increase in the preparation of the viscosity since the increase in the gelling agent is likely to strengthen the bond of the gel constituent matrix.

\section{Anti-inflammatory Test of The Gel}

The epidermal thickness was measured based on the average distance between the innermost and the outermost epidermal layer from three areas of each slice of rat's skin tissue under a microscope connected with the Toupview $($ software and 120 times magnification. The results of the measurement of epidermal thickness are presented in Figure 1 and Table 4.

The data (Table 2) and the result of HE staining (Figure 1) show that the smallest epidermal thickness is the normal group with a thickness of $403.02 \pm 21.56$ $\mu \mathrm{m}$, while the largest thickness is a negative control group was $683.16 \pm 30.14 \mu \mathrm{m}$. Kruskal Wallis' statistical analysis and Mann Whitney's post hoc were conducted to identify whether there is a difference among the groups. Mann Whitney is a statistical method to find out which groups are different by looking at the significance value of the two independent groups analyzed. This method used post hoc from Kruskal Wallis owing to its type of general analysis result. Therefore, the post hoc method is necessary to show specific results between the two groups compared to identify the best group in the research. Statistical analysis showed a significant difference $(\phi<0.05)$ between the normal and negative

\begin{tabular}{|c|c|c|c|c|c|c|}
\hline \multirow{2}{*}{ Replication } & \multicolumn{6}{|c|}{ Viscosity (Pa.s) } \\
\hline & GB $2.5 \%$ & GB 5\% & GF $2.5 \%$ & GF $5 \%$ & GC $2.5 \%$ & GC 5\% \\
\hline 1 & 2,753 & 1,322 & 1,113 & 1,153 & 1,627 & 1,394 \\
\hline 2 & 1,813 & 1,550 & 0.522 & 1,412 & 1,695 & 1,462 \\
\hline 3 & 2,237 & 1,153 & 1,246 & 1,415 & 2,217 & 1,700 \\
\hline$x$ & 2,267 & 1,342 & 0.960 & 1,327 & 1,846 & 1,519 \\
\hline SD & $\pm 0,4707$ & $\pm 0,1992$ & $\pm 0,3854$ & $\pm 0,1504$ & $\pm 0,3228$ & $\pm 0,1607$ \\
\hline
\end{tabular}




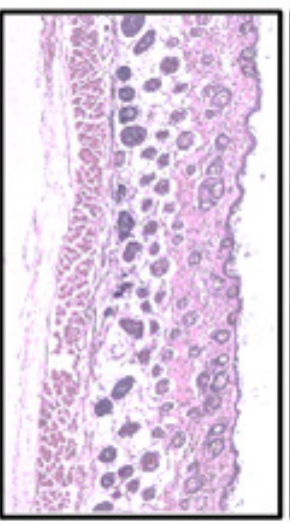

a

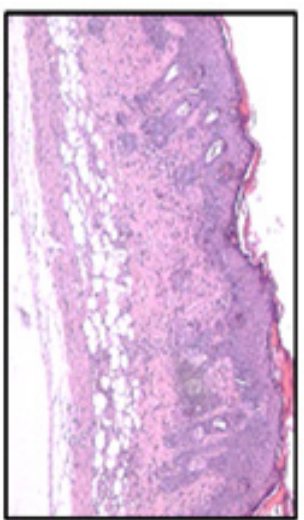

b

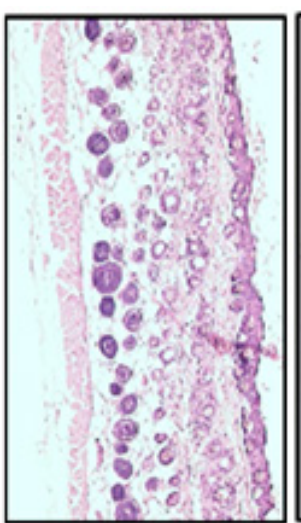

$c$

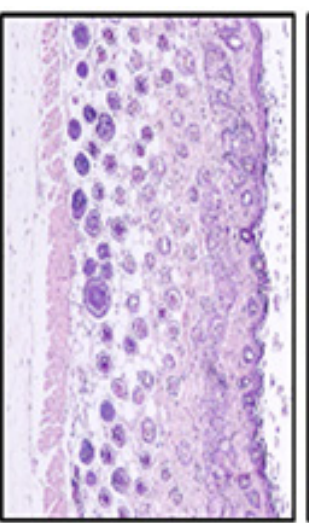

d

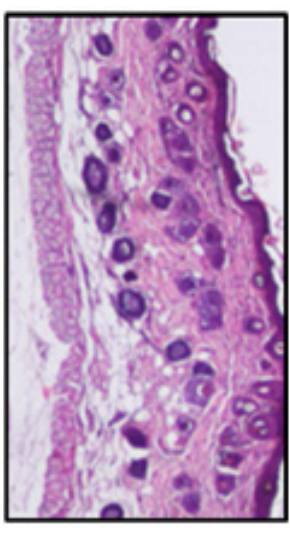

Figure 1: Microscopic depiction of skin tissue epidermal width by hematoxylin eosin (HE) staining of 120x magnification (a) normal, (b) negative control, (c) positive control, (d) extract group, and (e) gel formula group.

\begin{tabular}{|c|c|c|c|c|c|c|}
\hline \multicolumn{7}{|c|}{ Table 3: The results of the physical properties evaluation of gel preparations. } \\
\hline \multirow{2}{*}{ Characteristics } & GB 2.5\% & GB 5\% & GF 2.5\% & GF 5\% & GC 2.5\% & GC 5\% \\
\cline { 2 - 7 } Color & $\begin{array}{c}\text { Turmeric } \\
\text { Yellow }\end{array}$ & Brown & $\begin{array}{c}\text { Greenish } \\
\text { Brown }\end{array}$ & Black & $\begin{array}{c}\text { Blackish } \\
\text { Brown }\end{array}$ & $\begin{array}{c}\text { Dark } \\
\text { Brown }\end{array}$ \\
\hline Smell & $\begin{array}{c}\text { Distinctive } \\
\text { smell }\end{array}$ & $\begin{array}{c}\text { Distinctive } \\
\text { smell }\end{array}$ & $\begin{array}{c}\text { Distinctive } \\
\text { smell }\end{array}$ & $\begin{array}{c}\text { Distinctive } \\
\text { smell }\end{array}$ & $\begin{array}{c}\text { Distinctive } \\
\text { smell }\end{array}$ & $\begin{array}{c}\text { Distinctive } \\
\text { smell }\end{array}$ \\
\hline Form & Soft lumpy & Soft lumpy & Soft lumpy & Soft lumpy & Soft lumpy & Soft lumpy \\
\hline PH measurement & 6.03 & 6.03 & 6.12 & 6.04 & 6.09 & 5.73 \\
\hline $\begin{array}{c}\text { Spreadability } \\
\text { (cm) }\end{array}$ & 3.43 & 3.37 & 3.28 & 3.25 & 3.15 & 3.27 \\
\hline $\begin{array}{c}\text { Adhesion } \\
\text { (seconds) }\end{array}$ & 2.02 & 4.94 & 2.46 & 3.74 & 2.15 & 2.58 \\
\hline Viscosity (Pa.s) & 2,267 & 1,342 & 0.960 & 1,327 & 1,846 & 1,519 \\
\hline
\end{tabular}

Note : Data are presented by 3 -time replication

Note :

GB $2.5 \%$ : Gel with $2.5 \%$ of sidr leaves extract

GB $5 \%$ : Gel with $5 \%$ of sidr leaves extract

GF $2.5 \%$ : Gel with $2.5 \%$ of fig leaves extract

GF $5 \%$ : Gel with $5 \%$ of fig leaves extract

GC $2.5 \%$ : Gel with $2.5 \%$ of fig and sidr leaves extract combination GC $5 \%$ : Gel with $5 \%$ of fig and sidr leaves extract combination

groups so that the croton oil could be used to evaluate the anti-inflammatory activity of the tested gel formula. The difference in epidermal thickness was prompted by irritating croton oil which causes inflammation. The oil has an ability to activate phospholipase A2 which produces arachidonic acid. The acid is a metabolite that produces inflammatory mediators such as prostaglandins and leukotriene when it is metabolized by the body. ${ }^{20}$

The treatment groups in the anti-inflammatory activity test were rats induced with inflammation using croton oil and administrated with anti-inflammatory agents consisting of 12 kinds of groups. The treatment groups are $2.5 \%$ of sidr leaves extract, $5 \%$ of sidr leaves extract, $2.5 \%$ of fig leaves extract, $5 \%$ of fig leaves extract, $2.5 \%$ of sidr and fig leaves extract combination, and $5 \%$ of fig and sidr leaves extract combination. Meanwhile, the formulation groups consist of $2.5 \%$ of sidr extract gel, $5 \%$ of sidr extract gel, $2.5 \%$ of fig extract gel, $5 \%$ of fig extract gel, $2.5 \%$ of sidr and fig extract gel combination, and $5 \%$ of sidr and fig extract gel combination. The inflammatory application of all treatment groups onto the rats' skin showed that the application of anti-inflammatory agents to the extract group and gel formula was able to significantly reduce the epidermal thickness compared to negative controls $(p<0.05)$. A significant decrease in epidermal thickness indicated that the extract and gel formula from sidr and fig leaves have anti-inflammatory activity due to their flavonoid compounds. Flavonoids have potent anti-inflammatory activity in ethanolic extracts whose effects are similar 


\begin{tabular}{|c|c|}
\hline $\begin{array}{c}\text { Table 4: The results of epidermal thickness } \\
\text { measurement. }\end{array}$ \\
\hline Treatment group & Epidermal thickness $(\boldsymbol{\mu m})$ \\
\hline Normal & $407.07 \pm 23.65$ \\
\hline Negative Control & $678.90 \pm 110.61$ \\
\hline Positive Control & $408.57 \pm 33.82$ \\
\hline $2.5 \%$ of Sidr Extract & $429.15 \pm 14.63$ \\
\hline $5 \%$ of Sidr Extract & $446.09 \pm 16.04$ \\
\hline $2.5 \%$ of Fig Extract & $426.21 \pm 39.28$ \\
\hline $5 \%$ of Fig Extract & $454.55 \pm 40.01$ \\
\hline $2.5 \%$ of Combination Extract & $463.38 \pm 55.31$ \\
\hline $5 \%$ of Combination Extract & $458.60 \pm 19.64$ \\
\hline $2.5 \%$ Sidr Gel & $433.57 \pm 31.53$ \\
\hline $5 \%$ of Sidr Gel & $453.13 \pm 47.79$ \\
\hline $2.5 \%$ of Fig Gel & $439.09 \pm 19.87$ \\
\hline $5 \%$ of Fig Gel & $458.77 \pm 20.42$ \\
\hline $2.5 \%$ of Combination Gel & $464.49 \pm 30.27$ \\
\hline $5 \%$ of Combination Gel & $412.88 \pm 14.54$ \\
\hline
\end{tabular}

to the Indometacin NSAID drug. ${ }^{10}$ The significance of the results of the statistical analysis is shown in the following Table 5:

A significant reduction in thickness with the negative group showed various results when the treatment groups were compared to normal control. It was indicated by the statistical results of the $2.5 \%$ of sidr leaves extract group, $2.5 \%$ of fig leaves extract, $5 \%$ of fig leaves extract, $2.5 \%$ of fig and sidr leaves extract combination, $2.5 \%$ of sidr gel formula, $5 \%$ of sidr gel formula, and $5 \%$ of sidr and fig leaves gel combination that showed the similar conditions with normal control ( $p>0.05)$. Meanwhile, the treatment groups of $5 \%$ of the sidr leaves extract, $5 \%$ of fig and sidr leaves extract combination, $2.5 \%$ of fig leaves gel, $5 \%$ of fig gel, and $2.5 \%$ of sidr and fig leaves gel combination had not been able to achieve the similar conditions as normal control as they still exhibited significant differences $(p<0.05)$. The significance of the results of the statistical analysis is presented in Table 6 .

The decrease in epidermal thickness of the treatment group was compared using the Voltaren ${ }^{\circledR}$ positive control, which is a topical drug on the market. This test aims to assess whether the treatment group has the same anti-inflammatory activity as the drug on the market. The statistical test showed varied results. The treatment groups such as $5 \%$ of fig leaves extract, $2.5 \%$ of sidr and fig leaves extract combination, $5 \%$ of sidr and fig leaves extract combination, $5 \%$ of fig leaves extract gel, and $2.5 \%$ of sidr and fig leaves gel combination displayed a difference with a significance

\begin{tabular}{|c|c|c|c|}
\hline $\begin{array}{c}\text { Test } \\
\text { Parameter }\end{array}$ & \multicolumn{2}{|c|}{ The comparison group } & $\begin{array}{c}\text { Significance } \\
(95 \%)\end{array}$ \\
\hline \multirow{14}{*}{$\begin{array}{l}\text { The } \\
\text { Epidermal } \\
\text { Thickness }\end{array}$} & \multirow{14}{*}{$\begin{array}{l}\text { Negative } \\
\text { control }\end{array}$} & Normal control & $p=0.004$ \\
\hline & & Positive control & $p=0.004$ \\
\hline & & $\begin{array}{c}2.5 \% \text { of Sidr leave } \\
\text { extract }\end{array}$ & $p=0.004$ \\
\hline & & $\begin{array}{l}5 \% \text { of Sidr leave } \\
\text { extract }\end{array}$ & $p=0.004$ \\
\hline & & $\begin{array}{c}2.5 \% \text { of fig leave } \\
\text { extract }\end{array}$ & $p=0.004$ \\
\hline & & $\begin{array}{c}5 \% \text { of fig leave } \\
\text { extract }\end{array}$ & $p=0.006$ \\
\hline & & $\begin{array}{c}2.5 \% \text { of extract } \\
\text { combination }\end{array}$ & $p=0.016$ \\
\hline & & $\begin{array}{l}5 \% \text { of extract } \\
\text { combination }\end{array}$ & $p=0.004$ \\
\hline & & $2.5 \%$ of sidr gel & $p=0.004$ \\
\hline & & $5 \%$ of sidr gel & $p=0.006$ \\
\hline & & $2.5 \%$ of fig gel & $p=0.004$ \\
\hline & & $5 \%$ of fig gel & $p=0.004$ \\
\hline & & $\begin{array}{l}2.5 \% \text { of gel } \\
\text { combination }\end{array}$ & $p=0.006$ \\
\hline & & $\begin{array}{l}5 \% \text { of gel } \\
\text { combination }\end{array}$ & $p=0.004$ \\
\hline
\end{tabular}

\begin{tabular}{|c|c|c|c|}
\hline $\begin{array}{c}\text { Test } \\
\text { Parameter }\end{array}$ & \multicolumn{2}{|c|}{ The comparison group } & $\begin{array}{c}\text { Significance } \\
(95 \%)\end{array}$ \\
\hline \multirow{14}{*}{$\begin{array}{l}\text { Epidermal } \\
\text { Thickness }\end{array}$} & \multirow{14}{*}{$\begin{array}{l}\text { Normal } \\
\text { control }\end{array}$} & Negative control & $p=0.004$ \\
\hline & & Positive control & $p=0.688$ \\
\hline & & $\begin{array}{c}2.5 \% \text { of Sidr leave } \\
\text { extract }\end{array}$ & $p=0.054$ \\
\hline & & $\begin{array}{c}5 \% \text { of Sidr leave } \\
\text { extract }\end{array}$ & $p=0.013$ \\
\hline & & $\begin{array}{c}2.5 \% \text { of fig leave } \\
\text { extract }\end{array}$ & $p=0.377$ \\
\hline & & $\begin{array}{l}5 \% \text { of fig leave } \\
\text { extract }\end{array}$ & $p=0.092$ \\
\hline & & $\begin{array}{c}2.5 \% \text { of extract } \\
\text { combination }\end{array}$ & $p=0.149$ \\
\hline & & $\begin{array}{l}5 \% \text { of extract } \\
\text { combination }\end{array}$ & $p=0.008$ \\
\hline & & $2.5 \%$ of sidr gel & $p=0.173$ \\
\hline & & $5 \%$ of sidr gel & $p=0.055$ \\
\hline & & $2.5 \%$ of fig gel & $p=0.025$ \\
\hline & & $5 \%$ of fig gel & $p=0.008$ \\
\hline & & $\begin{array}{l}2.5 \% \text { of gel } \\
\text { combination }\end{array}$ & $p=0.010$ \\
\hline & & $\begin{array}{c}5 \% \text { of gel } \\
\text { combination }\end{array}$ & $p=0.688$ \\
\hline
\end{tabular}


value $(p<0.05)$. Meanwhile, the treatment groups such as $2.5 \%$ of sidr leaves extract, $5 \%$ of sidr leaves extract, $2.5 \%$ of fig leaves extract, $2.5 \%$ of sidr leaves extract gel, $5 \%$ of sidr leaves extract gel, $2.5 \%$ of fig leaves extract gel, and $5 \%$ of sidr and fig leaves extract combination gel showed the same epidermal thickness reduction activity as the positive control $(p>0.05)$. The significance of the results of the statistical analysis is presented in Table 7 as follows:

The decrease in epidermal thickness between the treatment groups was compared to identify the effectiveness of dosage and formulas, thus providing optimal anti-inflammatory effects. The extract treatment group showed a similar decrease in epidermal thickness ( $p>0.05$ ) except the $2.5 \%$ of sidr leaves extract group with $5 \%$ of sidr and fig leaves extract combination $(p$ $<0.05)$. The data in Table 2 shows that the epidermal width of the $5 \%$ combined extract group was $451.73 \mu \mathrm{m}$ greater than that of the $2.5 \%$ sidr extract group which was $425.36 \mu \mathrm{m}$. The formula treatment group also showed a similar decrease in epidermal thickness, except the $2.5 \%$ of fig gel group, $5 \%$ of fig gel group, and $2.5 \%$ and $5 \%$ of combination gel $(p<0.05)$. Furthermore, Table 2 shows the average of the difference in epidermal thickness that $5 \%$ of combination gel group had the smallest epidermal thickness of $412.88 \mu \mathrm{m}$ compared to those $2.5 \%$ of fig gel group at $439.09 \mu \mathrm{m}, 5 \%$ of fig gel group at $458.77 \mu \mathrm{m}$, and $2.5 \%$ of gel combination at $464.49 \mu \mathrm{m}$.

The anti-inflammatory activity of ethanolic extracts of fig leaves and sidr leaves was supported by a decrease in the number of inflammatory cells and a decrease in the expression of cyclooxygenase 2 (COX-2) enzyme descriptively examined under microscopic observation. The observation data are presented in Figures 2 and 3 as follows:

Based on Figure 2, it was found descriptively that the expression of the COX-2 enzyme was identified from its distinctive shapes, resembled a telephone's handle or brown color in the core or cytoplasm, while Figure 3 shows inflammatory cells marked with blackish patches. ${ }^{21}$ The observation result reveals that the appearance of inflammatory cells and COX-2 expression in negative controls were more than in the normal group. The result indicates that croton oil may cause inflammation on the skin. ${ }^{22}$ The number of inflammatory cells and the COX-2 expression of the treatment group, compared to the negative control and normal groups, appeared to have differences in appearance descriptively. It reveals that the results of the microscopic depiction of the formula group compared to the negative control show fewer numbers

\begin{tabular}{|c|c|c|c|}
\hline $\begin{array}{c}\text { Test } \\
\text { Parameter }\end{array}$ & \multicolumn{2}{|c|}{ The comparison group } & Significance \\
\hline \multirow{14}{*}{$\begin{array}{l}\text { Epidermal } \\
\text { Thickness }\end{array}$} & \multirow{14}{*}{$\begin{array}{l}\text { Positive } \\
\text { control }\end{array}$} & Normal control & $p=0.688$ \\
\hline & & Negative control & $p=0.004$ \\
\hline & & $\begin{array}{c}2.5 \% \text { of Sidr leave } \\
\text { extract }\end{array}$ & $p=0.261$ \\
\hline & & $\begin{array}{c}5 \% \text { of Sidr leave } \\
\text { extract }\end{array}$ & $p=0.076$ \\
\hline & & $\begin{array}{c}2.5 \% \text { of fig leave } \\
\text { extract }\end{array}$ & $p=0.470$ \\
\hline & & $\begin{array}{c}5 \% \text { of fig leave } \\
\text { extract }\end{array}$ & $p=0.025$ \\
\hline & & $\begin{array}{c}2.5 \% \text { of extract } \\
\text { combination }\end{array}$ & $p=0.037$ \\
\hline & & $\begin{array}{l}5 \% \text { of extract } \\
\text { combination }\end{array}$ & $p=0.025$ \\
\hline & & $2.5 \%$ of sidr gel & $p=0.109$ \\
\hline & & $5 \%$ of sidr gel & $p=0.173$ \\
\hline & & $2.5 \%$ of fig gel & $p=0.109$ \\
\hline & & $5 \%$ of fig gel & $p=0.025$ \\
\hline & & $\begin{array}{l}2.5 \% \text { of gel } \\
\text { combination }\end{array}$ & $p=0.030$ \\
\hline & & $\begin{array}{l}5 \% \text { of gel } \\
\text { combination }\end{array}$ & $p=0.336$ \\
\hline
\end{tabular}

of inflammatory and COX-2 cells. However, it implies a higher number of inflammatory cells and COX-2 expression compared to normal controls. Microscopic observations also compared between the positive controls and the treatment groups. The observations disclose that the number of inflammatory and COX-2 cells were relatively equal between those two groups.

The results of the statistical analysis and descriptive observation show that all raw extracts and formula treatments had a potential of anti-inflammatory effect on the rat's skin induced with inflammation using croton oil with a significance of $p<0.05$. The anti-inflammatory effect of the treatment groups also showed an effect similar to Voltaren ${ }^{\circledR}$ drugs on the market, even though the decrease in the epidermal thickness had not reached the normal conditions. Combination gel 5\% showed the best anti-inflammatory effect in the gel preparation group and $2.5 \%$ of fig leaves extract provided the best anti-inflammatory effect in the extract group. Meanwhile, $5 \%$ of the combination gel group and 2.5\% of fig leaves extract were tested statistically and obtained $p=0.419$ as the result indicating that both groups had similar anti-inflammatory activity. 
a

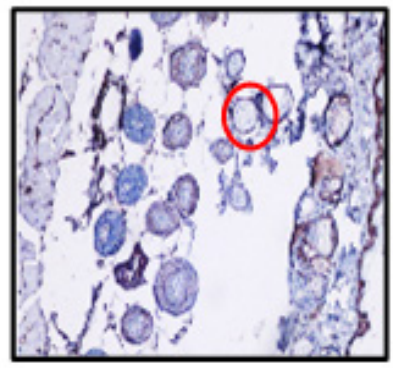

b
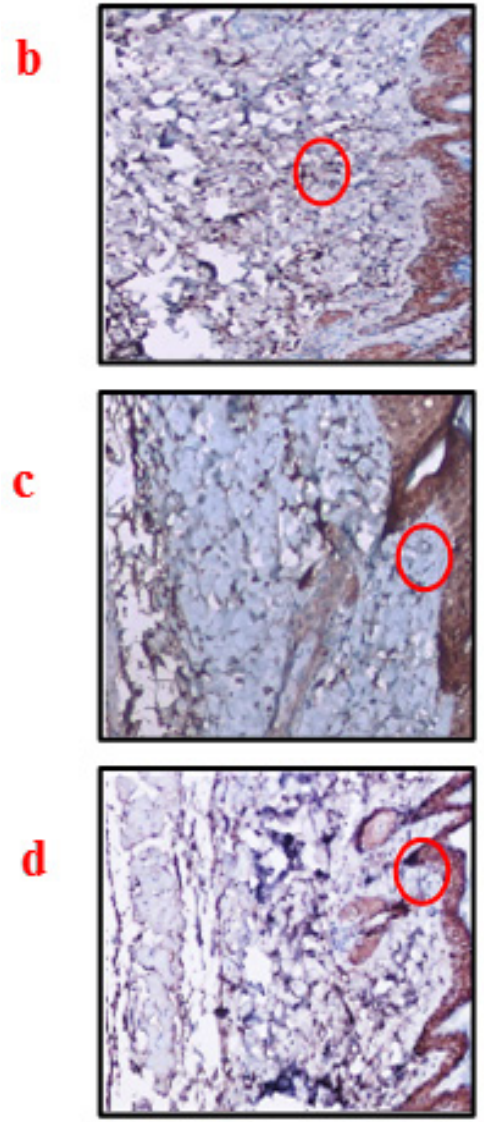

e
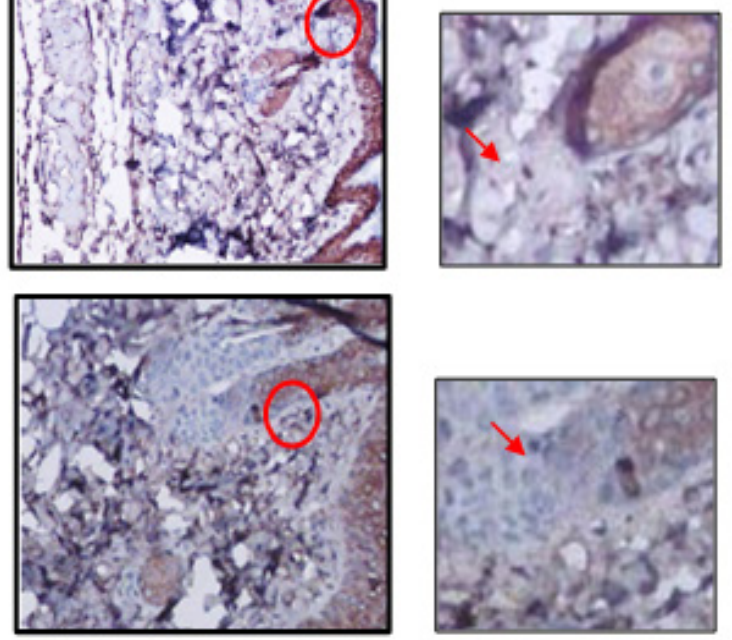

Figure 2: Microscopic depiction of COX-2 enzyme expression of skin tissue with $300 x$ magnification immunohistochemical staining along with zoom out (a) normal, (b) negative control, (c) positive control, (d) extract group and (e) gel formula group.

The calculation of the number of inflammatory cells, COX-2 enzyme expression, and epidermal thickness in the histopathological preparation stained with $\mathrm{HE}$ was conducted in three areas of each preparat of rat's skin tissue. Inflammatory cells were identified from blackishcolored patches, COX-2 expression was pinpointed by its distinctive shape resembled telephone's handle, and the epidermal thickness was calculated from the deviation between the inner and outer layers of the epidermal tissue of the rat's skin. This calculation was carried out upon the administration of immunohistochemical coloration into the preparation of the skin tissue using polyclonal COX-2 antibodies through a direct method. The antiinflammatory activity test of ethanol extract gel of fig leaves (Ficus carica Linn.) and sidr leaves (Ziziphus mauritiana Linn.) treated 15 treatment groups consisting of 6 male $\mathrm{BALB} / \mathrm{c}$ rats each group. The parameter of anti-inflammatory activity test was assessed from a decrease in the thickness of the epidermal tissue of the rat's skin, a decrease in the number of inflammatory cells, and a decrease in the amount of cyclooxygenase 2 (COX-2) enzyme expression.

The observation results reveal that the appearance of inflammatory cells and COX-2 expression in negative controls were more than in the normal group. The result indicates that croton oil may cause inflammation on the skin. ${ }^{22}$ The number of inflammatory cells and the COX-2 expression of the treatment group, compared to the negative control and normal groups, seemed to have differences in appearance descriptively. It reveals that the results of the microscopic depiction of the formula group compared to the negative control showed fewer numbers of inflammatory and COX-2 cells. However, it showed a higher number of inflammatory cells and COX-2 expression compared to normal controls. Microscopic observations also compared between the positive controls and the treatment groups. The observations exhibited that the number of inflammatory and COX-2 cells were relatively equal in number between the two groups. The results of the statistical analysis and descriptive observation show that all raw extracts and formula treatments had a potential of anti-inflammatory effect on the rat's skin induced with inflammation using croton oil with a significance of $p<0.05$. The anti-inflammatory effect of the treatment group also showed an effect similar to Voltaren ${ }^{\circledR}$ drugs on the market, even though the decrease in the epidermal thickness had not reached the normal conditions. Combination gel 5\% showed the best anti-inflammatory effect in the gel preparation group and $2.5 \%$ of fig leaves extract provided the best anti-inflammatory effect in the extract group. Meanwhile, $5 \%$ of the combination gel group and 2.5\% of fig leaves extract were tested statistically and obtained 


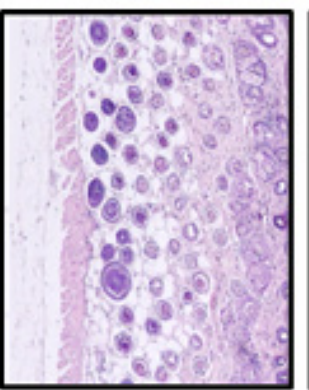

a

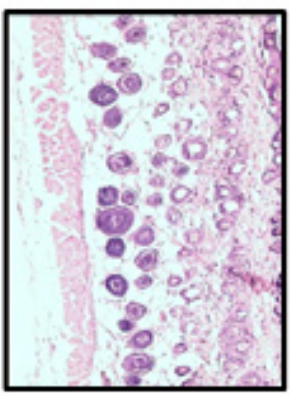

b

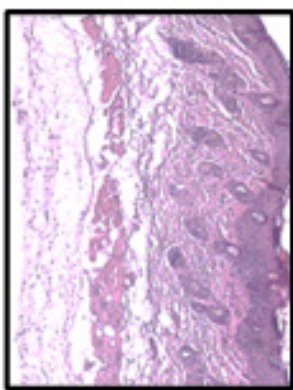

C

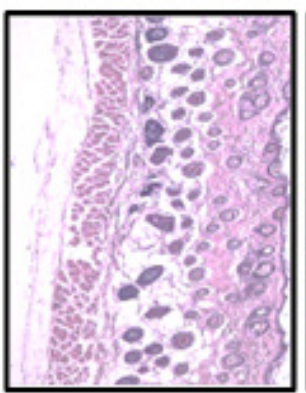

d

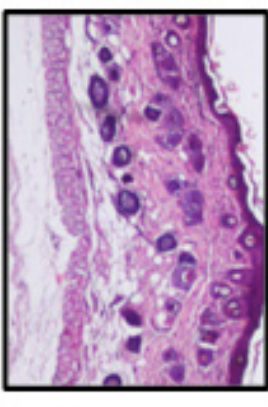

e

Figure 3: Microscopic picture of skin tissue inflammatory cells by 120x magnification hematoxylin-eosin (HE) and zoom out (a) normal, (b) negative control, (c) positive control, (d) extract group, and (e) gel formula group.

$p=0.419$ as the result indicating that both groups had similar anti-inflammatory activity.

\section{CONCLUSION}

In conclusion, this study found that the ethanol extract of fig leaves and sidr leaves had good physical properties based on good organoleptic test results, $\mathrm{pH}$ 5.73-6.12, adhesion $>1 \mathrm{sec}$, spreadability $\pm 3 \mathrm{~cm}$, and pseudoplastic properties of the gel fluid. The ethanol extract gel of fig leaves and sidr leaves had a potential of anti-inflammatory activity due to their significant effect on negative control based on epidermal thickness parameters $(p<0.05)$, number of inflammatory cells, and descriptive expression of COX-2 enzymes in the rat's skin tissue induced by croton oil. Furthermore, $5 \%$ of combination gel had the best anti-inflammatory activity in the treatment group based on the smallest epidermal thickness of $412.88 \pm 14.54 \mu \mathrm{m}$, the result of the statistical test with negative controls $(p=0.004)$, positive controls $(p=0.336)$, and normal controls $(p=$ $0,688)$. Furthermore, the result of a description of the number of inflammatory cells and the expression of COX-2 enzymes descriptively showed the least amount in the rat's skin tissue induced by croton oil.

\section{ACKNOWLEDGEMENT}

The authors gratefully acknowledge the School of Pharmacy Universitas Muhammadiyah Yogyakarta for providing research facilities.

\section{CONFLICT OF INTEREST}

The authors declare no conflict of interest

\section{ABBREVIATIONS}

COX-2: cyclooxygenase-2; Rpm: Revolutions per minute; HE: hematoxylin eosin; TEA: triethanolamine.

\section{REFERENCES}

1. Macovei LA, Birsan M, Teodor VI, Cristofor AC, loanid N, Rezus E. On the role of chemical and molecular biology in inflammation research. Rev Chim. 2017;68(4):786-8.

2. Villeneuve DL, Landesmann B, Allavena P, Ashley N, Bal-Price A, Corsini E, et al. Representing the process of inflammation as key events in adverse outcome pathways. Toxicological Sciences. 2018;163(2):346-52.

3. Kamatou GP, Vermaak I, Viljoen AM. Eugenol-from the remote Maluku Islands to the international market place: A review of a remarkable and versatile molecule. Molecules. 2012;17(6):6953-81.

4. Bouyahya A, Bensaid M, Bakri Y, Dakka N. Phytochemistry and ethnopharmacology of Ficus carica. Int J Biochem Res Rev. 2016;14:1-2.

5. Shad AA, Ahmad S, Ullah R, AbdEl-Salam NM, Fouad H, Rehman NU, et al. Phytochemical and biological activities of four wild medicinal plants. The Scientific World Journal. 2014;1-7.

6. Haeria M, Tenri AUDP. Penentuan Kadar Flavanoid Total dan Aktivitas Antioksidan Ekstrak Daun Sidr (Ziziphus spina-christi l). Journal of Pharmaceutical and Medicinal Sciene. 2016;1(2):57-61.

7. Ashraf A, Sarfraz RA, Anwar F, Shahid SA, Alkharfy KM. Chemical Composition and Biological Activities of Leaves of Ziziphus mauritiana L. Pakistan Journal of Botany. ;47(1):367-76.

8. Mohammad JH, Sikder MA, Mohammad AK, Mohammad RH, Chowdhury AA, Mohammad AR. Phytochemical and Biological Investigations of Methanol Extract of Leaves of Ziziphus mauritiana Lam. Boletín Latinoamericano y del Caribe de Plantas Medicinales y Aromáticas. 2015;14(3):179-89.

9. Kadioglu O, Jacob S, Bohnert S, Naß J, Saeed ME, Khalid H, et al. Evaluating ancient Egyptian prescriptions today: anti-inflammatory activity of Ziziphus spina-christi. Phytomedicine. 2016;23(3):293-306.

10. Patil VV, Patil VR. Evaluation Of Anti-Inflammatory Activity Of Ficus carica Linn. Leaves. Indian Journal of Natural Products and Resources. ;2(2).

11. Badgujar SB, Patel VV, Bandivdekar AH, Mahajan RT. Traditional uses, phytochemistry and pharmacology of Ficus carica: A review. Pharmaceutical Biology. 2014;52(11):1487-503.

12. Abdallah EM, Elsharkawy ER, Ed-Dra A. Biological activities of methanolic leaf extract of Ziziphus mauritiana. Pharm Commun Biosci Biotech Res Comm Thomson Reuters ISI ESC Crossref Index. J NAAS J Score. 2016;9(4):60514.

13. Kurniawan MF, Irawan MI, Prakoso A, Sugihartini N. Anti-inflammatory Activity Effect of Ficus carica and Ziziphus mauritiana leaves. International Journal of Pharmaceutical Research. ;12(1):920-7.

14. Rathod HJ, Mehta DP. A Review On Pharmaceutical Gel. International Journal of Pharmaceutical Sciences. ;1(1):33-47.

15. Voigt R. Buku Pelajaran Teknologi Farmasi, Diterjemahkan Oleh Soewandhi, S.N., Edisi V, 173, 179, 202-208, 577-578, 607-608, Gadjah Mada University Press, Yogyakarta. 1984

16. Kurniawan MF, Sugihartini N, Yuwono T. Uji Transport Emulgel Minyak Atsiri Bunga Cengkeh dengan Penambahan Enhancer Propilen Glikol dan Asam Oleat. Media Pharmaceutica Indonesiana. ;2(3):113-21. 
Fujiastuti T, Sugihartini N. Sifat fisik dan daya iritasi gel ekstrak etano herba pegagan (Centella asiatica L.) dengan variasi jenis gelling agent. PHARMACY: Jurnal Farmasi Indonesia. 2015;12(1):11-20.
20. Shah B, Seth A, Maheshwari K. A Review on Medical Plants as A Resource of Anti-inflammatory Agents. Research Journal of Medicinal Plant. 2011;5(2):101-15.

21. Sugihartini N, Saridewi R, Rahmawanti F, Yuliani S, Sophia V. Antiinflammatory Activity of Camellia sinensis, I. Extract Cream Combined with Vitamin $C$ as Antioxidant on Croton Oil-induced Inflamation in Male Mice Strain BALB/C. Majalah Obat Tradisional. 2017;22(2):73-9.

22. Lan M, Wan P, Wang ZY, Huang XL. Analisis GC-MS Komponen Kimia dalam Minyak Biji Croton tiglium. Zhong Yao Cai Journal. 2012;35(7):1105-8.

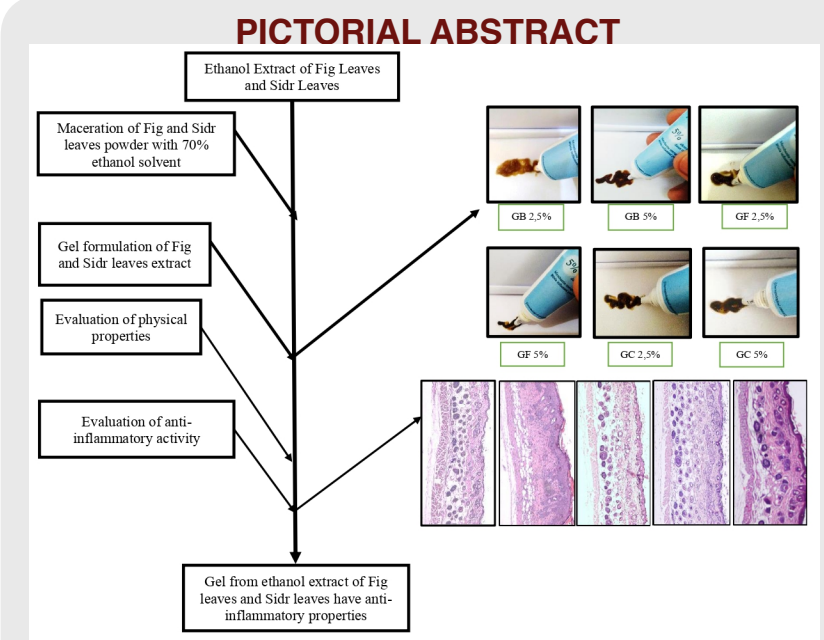

\section{SUMMARY}

The objevtive of the present study is to evaluate antiinflammatory activiy of ethanol extract of fig leaves and sidr leaves on gel dossage forms. This study found that the ethanol extract of fig leaves and sidr leaves had good physical properties. The ethanol extract gel of fig leaves and sidr leaves had a potential of antiinflammatory activity due to their significant effect on negative control based on epidermal thickness parameters, number of inflammatory cells, and descriptive expression of COX-2 enzymes in the rat's skin tissue induced by croton oil.

\section{About Authors}

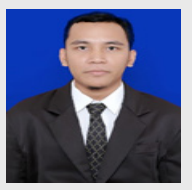

Muhammad Fariez Kurniawan is presently working as Lecturer in the School of Pharmacy, Faculty of Medicine and Health Sciences, Universitas Muhammadiyah Yogyakarta. He is now as Head of Pharmacy Physics Department on his institution.

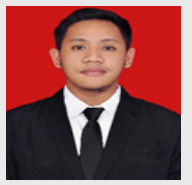

Ariffadli Prakoso Pursued his S.Farm from Medicine and Health Science Faculty, University Muhammadiyah Yogyakarta and Research under guidance of apt. Muhammad Fariez Kurniawan, M.Farm. His research work was focused on working with optimization of herbal cream formulation with in-vivo model of inflammation.

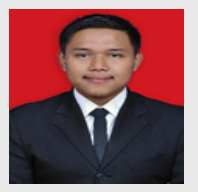

Muhammad Indra Irawan Pursued his S.Farm from Medicine and Health Science Faculty, University Muhammadiyah Yogyakarta and Research under guidance of apt. Muhammad Fariez Kurniawan, M.Farm. His research work was focused on working with optimization of herbal cream formulation with in-vivo model of inflammation.

Cite this article: Kurniawan MF, Prakoso A, Irawan MI. The Anti-inflammatory Effect of Ethanol Extract Gel of Fig Leaves (Ficus carica Linn.) and Sidr Leaves (Ziziphus mauritiana Linn.). Indian J of Pharmaceutical Education and Research. 2021;55(2s):s518-s527. 